\title{
РУСЬКА МОВА В РЕЦЕПЦІї ЗАХІДНОРУСЬКОЇ ДУХОВНӦ̈ ЕЛІТИ ОСТАННЬОЇ ЧВЕРТІ ХVII ст.
}

\author{
IPИНА ФАРІОН
}

Верховна Рада України, голова підкомітету з питань вищої освіти — Україна

\author{
JEZZYK RUSKI W RECEPCJI ZACHODNIORUSKIEJ \\ ELITY DUCHOWNEJ OSTATNIEGO ĆWIERĆWIECZA XVII w.
}

\author{
IRYNA FARION \\ Rada Najwyższa Ukrainy, \\ Przewodniczący Podkomitetu ds. Szkolnictwa Wyższego — Ukraina
}

STRESZCZENIE. W artykule zbadano rolę i miejsce języka ruskiego (ukraińskiego) W systemie wartości społeczno-religijnych zachodnioruskiej elity duchownej. W centrum badania znajduje się świadomość językowa wybitnych przedstawicieli duchowieństwa unickiego - metropolity Cypriana Żochowskiego, biskupów Josypa Szumlanskiego, Innocentego Winnickiego i ks. Piotra Kaminskiego.

\section{RUS'KA LANGUAGE IN THE PERCEPTION BY WEST RUS ECCLESIASTICAL ELITE OF THE LAST QUARTER OF THE XVII CENTURY}

\section{IRYNA FARION}

Verkhovna Rada of Ukraine, Head of Higher Education Subcommittee — Ukraine

ABSTRACT. In the article the role and place of the Rus'ka (Ukrainian) language is researched in the system of social and religious values of West Rus' ecclesiastical elite. The research is focused on the language consciousness of the significant representatives of Uniate Clergy, namely metropolitan Kyprian Zhochovskyj, bishops Iosyf Shumliansky and Innocenty Winnicki and priest Petro Kaminskyi.

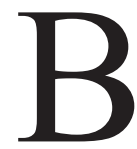

ивчення історичної соціолінгвістики крізь призму мовної свідомості один із новітніх напрямів сучасного українського мовознавства. Такий підхід уможливлює реконструкцію історичної мовної дійсності та особистісної мовної свідомості в контексті синтезу наук: історії, філософії, релігії, соціології і власне мови. Мовна особистість - фокус світогляду епохи, „прочитання" якого крізь призму двох рівнів мовної особистості - ієрархії смислів та цінностей особистості в картині світу й вищого рівня, тобто ії мотивів та цілей ${ }^{1}$ - уможливить реконструкцію філософії мови особистості і їі часу.

Для останньої чверті XVII ст. характерне релігійно-містичне трактування сутності та природи людської мови й оцінно-ієрархічна шкала суспільного побутування різних мов на тлі різних суспільно-релігійних та мистецьких течій: відгомону Реформації, Контрреформації та Бароко. Звідси полілінгвізм, а також суперечливість та співжиття різних мовних світів в одній МО. Маємо на меті дослідити цей процес розмаїтого мовного буття крізь призму найяскравіших духовних постатей українського ранньомодерного часу Західної Украї-

${ }^{1}$ Ю. Н. Кар ауло в, Русский язык и языковая личность, Москва 1987, с. 37. 
ни та виявити їхні руськомовні, тобто українські, виміри в контексті формування етно-національної свідомості. Першорядне завдання цієї статті — досліди-

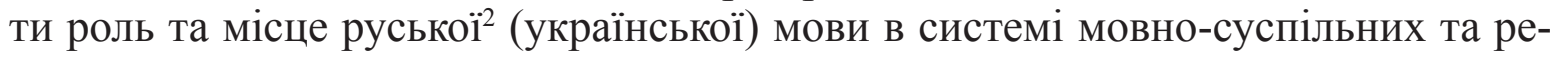
лігійних цінностей тодішньої західноукраїнської духовної еліти.

Серед духівництва Західної України до найякравіших постатей останньої чверті XVII ст., що виразно виписали свої мовні переконання в релігійній царині, належать унійний митрополит Кипріян Жоховський (1674-1693рр.), єпископ львівський Йосип Шумлянський (від 1668 р.), який 1700 р. приєднав своє єпископство до унії, хоч сам був таємним уніятом з 1677 р., та єпископ перемишльський, самбірський, сяноцький Інокентій Винницький (1680-1700рр.) уніят із $1691 \mathrm{p}$.

Єпископ Йосип Шумлянський та митрополит Кипріян Жоховський є авторами знакового руськомовного документа, складеного на сеймі, зі злободенною назвою ще від часів Велямина Рутського та Петра Могили: Спосіб згоди ц̧ерков, тобто Церкви східної з Церквою західною в Польському королівстві, щзо лишаються під щзасливим пануванням його королівської милости, пана нашого милостивого, із задоволенням усього руського народу (1681р.). У другому пункті документа акцентовано увагу на опосередкованому забезпеченні соціальної основи носіїв руської мови і вплив на цей процес духівництва: „Просимо, щоб руські уряди роздавалися за згодою руського духовенства монастирів кожної єпископії, згідно прав, тільки Русі"з .

Другою проблемою в утвердженні руської мови була потреба свого друкарського центру в Західній Україні. Щойно новий унівський архимандрит Варлаам Шептицький наприкінці 1669 р. здобув королівський привілей на „друкарню слов'янську і руську", Унів став православним центром друкарства на Західних землях. Заслугою Унівської друкарні була передусім публікація богословських, катехитичних та релігійно-моралізаторських творів переважно руською мовою, зокрема 1670 р. в Уневі передруковано з ранішого київського видання Виклад о иеркві Феодосія Софоновича, в додатку до якого вміщено переклад руською мовою Житія князя Володимира. Того ж року побачила світ написана тогочасною писемною українською мовою книжка єпископа Йосифа Шумлянського Зерцало до прейзріння і латвійшого зрозуміння віри святої, разом із якою видано твір Сильвестра Косова $O$ мистирія $x^{4}$.

Серед унівських видань особливе місце посідає Требник 1681 р. 一 це церковна книга, що тлумачить, як виконувати святі дійства й уділяти святі тайни для надприродного освячення вірних. Водночас це енциклопедія церковного богослов'я - отже, моральна догматика й право, з додатком пасторального богослов’я. Дослідник зауважив: „Пересипуючи часто словами живої тодішньої говірки, він є також доказом для нашої мови. <..> Між ними є постійно вживана буква г у тих словах, де ми й досі вимовляємо г, як наприклад Панагія..."5.

Стефан Семчук повідомляє про ще один Требник, щоправда, без ста початкових сторінок та браку низки сторінок усередині та наприкінці. Графіка цього Требника та характер його наповнення свідчить, що він з того самого часу,

${ }^{2}$ У дослідженні використовуємо термін руська мова, себто украӥнська, як постійно вживаний у досліджувану пору.

${ }_{3}^{3}$ Остання чверть XVII - початок XVIII cm., [в:] Тисяча років украӥнської суспільно-політичної уумки в 9 m., Київ 2001, т. 3, кн. 2, с. 183.

${ }_{4}^{4}$ Я . І с ає в ич, Українське книговидання: витоки, розвиток, проблеми, Львів 2002, с. 276-277.

${ }^{5}$ C. С е м ч у к, Унівський Требник 1681 р., [в:] ,ЗЗаписки ЧСВВ”, секція II, т. IX (XV), вип. 1-4, Рим 1974, с. 140. 
порівн.: „А найцікавіше те, що в Молебні на Ісход душі священик питає хворого руським язиком, і слідує розмова тодішньою живою говіркою між священиком і недужим; питання і відповіді надзвичайно цікаві так під оглядом мовним, як ще більше під оглядом богословським і побуту. Це повні чотири сторінки такої розмови"6.

Катихизіс албо наука хр(ис)тіанская, вкоротиь з розныхъ авторовъ зебранная за благословенням єпископа перемишльського Інокентія Винницького (в додатку до нього вміщено трактат Наука або способ диспонованя ся на смерт кожному християнину) ${ }^{7}$. Катихизіс використовували священики як підручник під час читання проповідей у церкві. Цікаво, що ця праця викликала спротив у Римі як начебто така, що в шістьох позиціях має догматичні відхилення від науки Римської Церкви ${ }^{8}$. 3 огляду на це, виникла ідея просто видрукувати відомий катехизм Карла Барберіні руською мовою. Однак здійснити це виявилося неможливо, бо внаслідок ухвали Самбірського з'їзду Інокентій Винницький 1691 р. приєднався до унії. Як наслідок, православна Унівська друкарня відмовилася друкувати вже унійний Катихизіс, як і Устави синоду 1693 р.

Показовими є роздуми єпископа щодо безпроблемної можливості видати цю працю в Кракові польською мовою. На думку єпископа, це принесе набагато меншу користь, позаяк багато людей у Перемишльській єпархії, а навіть серед клиру, знають тільки руську мову, нею моляться та вживають ії в щоденному житті, що засвідчує широку суспільну основу побутування руської мови. В іншому своєму листі єпископ докладніше стверджує, що „духовенство Перемишльської єпархії здебільшого користується тільки слов'янською мовою при своїх священних чинностях, а по-польськи навіть не вміє читати”. „Тим більше, що деякі (люди) менше освічені відчувають навіть відразу до польської мови і підозрівають, що грецький обряд $є$ вже змінений або мають його поволі змінити". Отже, вживання мови перебувало в прямому зв'язку з належністю до конфесії.

Після тривалих перемовин із православною монастирською друкарнею в Уневі, що закінчилися відмовою, і синодальні Устави, і Визнання православної віри перекладено польською мовою. Наголосимо, що наради синоду відбувалися руською мовою і тією ж мовою був схвалений і підписаний учасниками текст синодальних Уставів, тоді як віросповідання складено поцерковнослов' янському ${ }^{10}$.

Висловлена мотивація щодо польського перекладу додатково підтверджує усвідомлену потребу мати важливі друки саме руською мовою й водночас повторює заяложену думку про термінологічну латино-руську невідповідність: „... деякі слов'янські терміни, зокрема в богословських питаннях, ще більше аніж у латинській мові, спричиняють неясність так, що їх і на самій Русі не всі можуть вияснити. Тому для легшого зрозуміння не тільки самої Руси, щоб не здавалося простолюддю, що це якась інша, а не та, яка в первісній церкві була віра, але також і для розуміння людей обряду римського, щоб, бачачи тотожність віри, від грецького обряду... не відстрашувалися" ${ }^{11}$. Цей текст

${ }^{6}$ Там само, с. 141.

${ }^{7}$ Я. І с ає в ич, зазн. джерело, с. 277; М. Корзо, Украинская и белорусская традиция конияа XVI-XVII вв.: становление, эволюичя и проблема заимствований, Москва 2007, с. 429.

${ }^{8}$ Б. Балик, Інокентій Іван Винницький. Спископ перемиський, самбірський, сяніиький (1680-1700), [в:] „Записки ЧСВВ”, секція I, серія 2, Рим 1978, с. 239-240.

${ }^{9}$ Там само, с. 242.

${ }^{10}$ Там само, с. 256.

${ }^{11}$ Там само, с. 259. 
скеровано митрополитові Кипріянові Жоховському, на що він дав прихильну й схвальну оцінку.

Набагато печальнішу мовну картину буття духівництва прочитуємо з унікальної публіцистичної польськомовної праці Манускрипт... отця Петра Камінського, авдитора унійної митрополії при митрополитові Кипріянові Жоховському (Манускрипт велебного отия Петра Камінського, писаний до певного уніята Литовського, але не докінчений (1686 р.)) з мовно заакцентованим розділом Дезертири з латинського обряду у відношенні до грецького обряду й руської мови ${ }^{12}$.

Цей твір — наслідок конфліктів у середовищі уніятів, написаний з позиції консервативної частини духівництва - прихильників грецького обряду. У праці йдеться про негативну реакцію на можливу участь римо-католицьких єпископів (латинників) у виборах грецьких (себто греко-католицьких) єпископів. Отцеве обурення випливає з низки чинників, серед яких і мовний: „Ба й смішно було б: латинники вибирають руського єпископа, котрий потім, вибраний, нінащо їм не здався б, ані обрядом, ані мовою, ані релігійними практиками. Хіба що схотіли б русинами поставати, - то інша річ, або обряд змішати і все горі коренем перевернути - то не річ, а насильство"13. Отець наголошує на біблійних джерелах апостольського розмаїття мов та силі предківських традицій, зречення яких не призводить до добра: „Але духовний, що має управляти не тілом, а душами, мусить бути таким управителем, який би спасенною наукою покріпляв підлеглих собі, що без особи того самого обряду, мови й віри не може бути. Нащо Дух Святий для навчання і ведення до спасіння дав апостолам різнорідність мов?. Отже, трудно $з$ новим і грізним для цілої Руси явищем погодитися нам, що держимося права й хочемо стояти силою давніх звичаїв, знаючи, що нічого певного, коли відступитися від закону"

Криза вживання руської мови безпосередньо торкнулася священичої практики, порівн.: „Руською мовою так бридяться, що в цілій унії не почуєш руської проповіді; по-польськи теж ледви хто вміє; всі говорять по-уніятськи. I слушно: як церемонії мішані з грецьких і латинських, так і мова 3 польського й руського мішана; у всім мішанина, приміром: pójdź do okna - пайзі к вакну; wiatr - віцєр; drzewo - дзєрєво; będzie - будзє (прим. П. Камінський як українець, будучи на візитації в Білорусі, сприймав білоруську мову як суміш польської та української) і т. д. Особлива вимова, пожалься, Боже губи!. Тому й мудрі уніяти, що, не читаючи зовсім добре по-руськи, задля стиду правлять по келіях читані служби Божі" ${ }^{15}$.

Зазначений автор відтворює не лише викривлену соціолінгвістичну атмосферу, але й наголошує на важливій власне мовознавчій проблематиці. Йдеться про розгортання контексту культури мовлення й негативної оцінки мішаної, макаронічної мови (по-теперішньому - суржику), вмотивовуючи це явище глибинними ментально-суспільними процесами, порівн.: „... самі не знають, що роблять, так помішалися”, „... ми ані Русь, ані ляхи”16, „... і що ми єсьмо? Ляхи не ляхи, Русь не Русь. Русь на італійських ногах. Лучалося часом, що дехто з наших братів або отців переходив до уніятів; радо їх приймали, бо звичайно вони в руській мові вправні, бувають 3 них добрі співаки або ремісники"17. На-

\footnotetext{
${ }^{12}$ Остання чверть XVII - початок XVIII cm., [в:] Тисяча років..., с. 260.

13 Там само, с. 209.

${ }^{14}$ Там само, с. 210.

${ }^{15}$ Там само, с. $263,254$.

${ }^{16}$ Там само, с. 255 .

17 Там само, с. 259.
} 
голос на антропонімній лексиці як етнічному ідентифікаторові вкотре засвідчує національне самоусвідомлення отця Петра Камінського, а отже, і загальне сприйняття суспільством антропоніма як коду у відмиканні свого - чужого, порівн.: „Всі руські князі — куди вони поділися? Тільки з імен їхніх чуємо, що була колись Русь княжа” 18 ; „Інші криються 3 тим, що вони русини, і забираються в чужі краї, позмінювавши прізвища"19.

Такий загальний стан відчуження від свого міг привести лише до логічного прохання правити Службу Божу латинською мовою: „В 1683 р., як сказано, вислали з Жировичів отця Малеєвського до Рима 3 просьбою, щоб їм дозволено відправляти богослужіння в латинській мові. Спротивився тому його милість отець митрополит і писав до Риму при листах його королівської милости, виставляючи непорозуміння, які можуть 3 того вийти. <..>. Вже й до того було прийшло, що ченців простих і не свідомих латини отець Малеєвський називав хлопами і підданими. А грецький обряд у такій погорді $є$, що в Жировичах не говорено інакше, тільки що руське набожество - хлопське набожество. Так зовсім були тої надії, що мали одержати з Рима дозвіл на зміну обряду; бо й так намовляли Римові: що нема такої небезпеки, аби не могли перейти на латинський обряд. Не так воно було раніше, коли з Руси мало хто вмів по-латинськи і були в мороці; тепер з ласки Божої, вони вже в яснім світі дня (слова отця Огилевича: у найсвітлішого світлий полудень), бо тридцять уніятів знає латину. - Бувай здоровий! "20.

Цей блискучий твір за публіцистичною силою, національним самоусвідомленням, світоглядовою позицією можна вважати квінтесенцією полярного ідейного наповнення того часу: національного відступництва одних та відданості інших. Траєкторія функціювання руської мови в унійних колах, напр. XVII ст., після високих руськомовних поривів Велямина Рутського, ударів приглушення iї в часи козацьких змагань знову зазнала спаду перед відродженням у XVIII ст. Польськомовність цієї патріотичної праці вкотре підтверджує, що вибір мови твору на ту пору не означав національного відступництва, а був виявом ,загального духу того часу”, і лише „одиниці спроможні були піднятися над загальною - як правило, негативною — опінією та утверджувати свою національну ідентичність — і насамперед у мові"21.

Підтверджує цю думку життєвий і творчий шлях унійного єпископа Холмського Якова Суші (1610-1687), що, представляючи найзахіднішу гілку українців і опинившись після козацької поразки під Берестечком в адміністративному складі Польщі, гідно витримував удари католицького польського клиру. Всі його твори написано латинською мовою (листи до папи, De laboribus Unitorum... (1664 p.), Status recens Unionis (1664 p.), Cursus vitae... (1655 p.), Saulus et Paulus ruthene Unionis... (1665 p.), Phoenix tertiato (1684 і 1689 pp.), за винятком польськомовного листа до гетьмана Івана Виговського 1658 р. (з рясним церковнослов'янським цитуванням) та листів до полковника Павла Тетері ${ }^{22}$.

Особливе історико-церковне, а за I. Франком, і літературне значення мало повчання Йосифа Шумлянського духівництву Метрика альбо рєєстръ...

\footnotetext{
${ }^{18}$ Там само, с. 223.

${ }^{19}$ Там само, с. 214.

${ }^{20}$ Там само, с. 260.

${ }^{21}$ П. В. Шкраб'юк, Монаший Чин Отиів Василіян у національному житті Украӥни, Львів 2005, с. 283, 169.

${ }^{22}$ I. Н аз ар ко, Яків Суша - єпископ Холмський (1610-1687), [в:] „Записки ЧСВВ”, секція II, т. 7 (ХІІІ), вип. 1-4, Рим 1971, с. 41, 82-83.
} 
$(1687 \text { р. })^{23}$, що вийшла в друкарні монастиря св. Юра, заснованій самим єпископом. Це своєрідний посібник для духівництва про працю в парохіях. Характерним відображенням зміни мовної свідомості того часу є те, що праця „писана гарною, живою і близькою до народної мовою"24. І хоч почасти виникали сумніви, чи, бува, не інша людина, що дуже добре володіла руською мовою, писала на замовлення цю Метрику, однак віднайдений руськомовний вірш єпископа Дума сповна підтверджує саме його авторство цих двох творів.

У Метрищі єпископ пояснює написання своєї праці руською мовою не тільки практичним міркуванням „для снаднЊйшаго кождому вырозум'нья” (, для кращого розуміння"), але вперше серед духівництва апелює до рідної руської мови, протиставляючи іiі мові слов'янській: „Сія и въ той новой книжици судихомъ типомъ изъяснити, и для снаднЊйшаго кождому вырозум'нья, не Словенскимъ языкомъ, але нашимъ прирожонымъ Російскимъ діалектом изволихомъ писати, архіерейско и пастырско всъхъ вобще и кожного зособно упоминаючи...”25. Поряд із тим, „слов'янське письмо” традиційно ідентифіковано як „своє”: „... пврв ьй своєгФ словєнскогФ писма, и Азыка добрє наоучивши, потомъ до школь польских и лати(н)ских нє заборонАли...”26.

Автор подає широкий соціолінгвістичний розріз проблеми, що певною мірою суголосний з міркуваннями Петра Могили в його Літосі та Сильвестра Косова в Exegesis-i про супільно-політичну потребу, проживаючи в Короні Польській, знати польську мову й, не завадило б, — латинську. Як і Сильвестр Косов, він звертає особливу увагу на суспільне приниження, якого зазнають русини, коли не знають латинської та польської мов. Характерно, що спосіб вирішення цієї проблеми єпископ бачить не лише в суспільній потребі вивчати латинську та польську мови, а вивчати й свою, рідну, порівн.: „такъ р8скогФ слов $($ н)скагш,

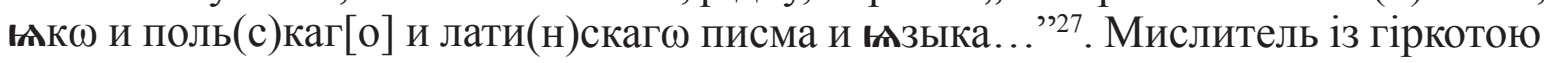
стверджує: „Наслухалися есьмо и того досить, якъ намъ панове духовенство Рымское, а часом и ляда кто примовляють, простотою называють насъ, неуками; а то для того, же Латинського письма, альбо Польского многіе не розум Њють, и языкомъ Латинскимъ, альбо Польскимъ мовити не ум'юютъ. Хочай другій священникъ въ Словенскомъ языку и письм' будете добр' учоный и уметный, и, здается, большъ ум'ъти былъ бы не повыненъ, только кождый своего власного язика добрt письмо: але, же Латинского языка альбо Польского не ум'еть, то южъ у пана простакъ. И не дивуймося тому: бо и апостоловъ святыхъ, зъ початку, поганство за таковыхъ простаковъ и неуковъ розумЊло, и о томъ Павелъ святый нам'няетъ, мовячи до КоринӨянъ: „Мы убо буіи Христа ради, ві же мудріи о Христь”. Але, поньважъ и Павель святый оть священника и науки потребуетъ, гды мовитъ: „подобаетъ же епископу (альбо священникови) быти учительну»; и сама слушность, альбо потреба духовная того по насъ вытягаеть (але и туть, въ краях короны польской), абы духовенство наше Россійское православное духовенству Рымскому принамньй языкомъ корреспондовало, же бы священникъ зъ паном пол'ттин' могль ся розмовити, и на задане якой трудности уметн' отпов Вдати. Пре то потреба овшеки духовенству нашему ту-

${ }^{23}$ Собори Львівської єпархії XVI- XVIII cm., Львів 2006, с. 225-247.

${ }^{24}$ I. Франко, П. Житеикий. „Энеида” И. П. Котляревского и древнейший список ее, [в:] його ж, Зібрання творів у 50 m., Київ 1982, т. 33, с. 431.

${ }_{25}$ Акты, относящиеся къ истории Западной Россіи, собранные и изданные Археографическою коммиссіею, СПб. 1853, с. 197.

${ }^{26}$ Собори Львівської єпархії... с. 232.

${ }^{27}$ Там само, с. 233. 
тейшому, не только Словенского, але и Польского писма, а если можно и Латинського быти умњетному"28. Про нестримні полонізаційні процеси свідчать польськомовні й латиномовні документи Йосипа Шумлянського та до нього, зокрема, від польського короля Августа II та латиномовний до нунція Ніколо Спінолі на початку XVIII ст. ${ }^{29}$

Підсумовує бурхливе XVII ст. один із найважливіших руськомовних творів в історії церковно-літургійних видань Унійної Церкви - Служебник митрополита Кипріяна Жоховського 1692 року. Ця праця продовжує традицію видання Служебників ще у видавництві Мамонича 1617 р., зокрема промовистими $\epsilon$ україномовні освячувальні формули, започатковані 1617 р.: „Прійміте: Се єст Тセло моє” і „Пійте: Се єст Кров моя” в дусі рішення Віленської Василіянської капітули 1667 р., а не „Сія єст Кров моя” „Твоя от твоихъ тебњ приносимо” (замість ,приносяще”) ${ }^{30}$.

3 огляду на досліджене, можемо твердити, що виникнення руської Унійної Церкви внаслідок унії 1596 р. — це не лише вислід світової і місцевої кризи православ'я, але „вестернізований” витвір реформаційно-ренесансової доби, а відтак, один із визначальних чинників українського етнотворення, всупереч усталеним досі кордонам конфесійності. На слушну думку Д. Донцова, „прив'язаний церковно до Риму, наш нарід тисячею ниток був би тим самим прив'язаний до Заходу загалом, до його культури" 31 . Поза тим новостворена Унійна Церква (крім поширеного тоді лементу про зраду) внесла у свідомість клиру та мирян нове трактування єдності: не конфесійне, а етнічне („Руси 3 Руссю”), і руська мова в тих процесах посіла далеко не другорядну роль, попри подальше тяжіння клиру до, так званого, „нашого церковнослов’янського язика” й одночасного протиставлення його руській мові. „Вестернізований” релігійний вибір заклав основи нового структурування суспільної свідомості з визначальним етногенетичним та мовним чинником як передвісником української модерної нації.

Знаково, що на місце знищеної в другій половині XVII ст. руської Православної Церкви в останній чверті XVII ст. на сторожі української ідентичності стає Унійна Церква, зокрема через утвердження руської мови в трьох основних виявах: комунікативно-прагматичному (потреба спілкуватися 3 Богом зрозумілою, рідною мовою, про що свідчать міркування Інокентія Винницького та Йосифа Шумлянського), соціально-психологічному (неоднозначна шкала оцінки руської мови від позитивів у Йосифа Шумлянського та Інокентія Винницького до викривальної критики у творах Петра Камінського) та філологічному (від констатації проблем культури мовлення до антропонімної ідентифікації у праці Петра Камінського).

${ }^{28}$ Акты, относящиеся къ истории Западной Россіи ..., с. 202-203; Собори Львівської єпарxiï..., c. 232-233, c. 242-243.

${ }^{29}$ Архивъ Юго-Западной Россіи, издаваемый временною коммиссіею для разбора древнихъ актовъ, высочайше учрежденною при Кіевскомъ Военномъ, Подольскомъ и Вольнсккомъ генералгубернаторе. Постановленія дворянскихъ провиниіальныхъ сеймовъ, въ Югозападной Россіи, Киев 1904, ч. I, т. 12, с. 600-602, 607-613, 615-618.

${ }^{30}$ М. М. В а в р и к, Служебник митр. К. Жоховського 1692 р. (Генеза й аналіза), [в:] „Записки ЧСВВ”, секція II, т. 12 (XVIII ), вип. 1-4, Рим 1985, с. 337.

${ }^{31}$ Д. Донцов, Унія, [в:] його ж, Вибрані твори у 10 m., Культурологічна та історіософська есеїстка (1911-1939), Дрогобич-Львів 2012, т. 2, с. 134. 